\title{
Quantitative assessment of tree species diversity of Himchari National Park (HNP) in Cox's Bazar, Bangladesh
}

\author{
SADDAM HOSSEN ${ }^{1, \bullet}$, MOHAMMED KAMAL HOSSAIN ${ }^{2}$, MD. AKHTER HOSSAIN ${ }^{2}$, \\ MOHAMMAD FAHIM UDDIN ${ }^{2}$ \\ ${ }^{1}$ Department of Forestry and Environmental Science, Rangamati Science and Technology University. Rangamati-4500, Bangladesh \\ Tel.: +8801913291487, `email: saddamhossen.cu@gmail.com \\ ${ }^{2}$ Institute of Forestry and Environmental Sciences, University of Chittagong. Chittagong-4331, Bangladesh
}

Manuscript received: 13 May 2020. Revision accepted: 28 September 2020.

\begin{abstract}
Hossen S, Hossain MK, Hossain MA, Uddin MF. 2020. Quantitative assessment of tree species diversity of Himchari National Park (HNP) in Cox's Bazar, Bangladesh. Asian J For 5: 1-7. Himchari National Park (HNP) in Cox's Bazar is an important conservation area in Bangladesh that is threatened by human disturbances, urging for vegetation assessment for monitoring and management purposes. The aim of the study was to assess the tree species diversity, composition and structure of HNP through stratified random sampling method using sample plots (51) of $20 \mathrm{~m}$ x $20 \mathrm{~m}$ in size during the period of January 2017 to May 2018. A total of 961 stems $(\mathrm{dbh} \geq 5 \mathrm{~cm})$ of 88 tree species belonging to 64 genera and 37 families were enumerated where the stem density and basal area were 457.39 stem ha $^{-1}$ and $10.979 \mathrm{~m}^{2}$ ha $^{-1}$ respectively. On the other hand, the species diversity index, Shannon-Wiener's diversity index, Shannon's maximum diversity index, species evenness index, Margalef's diversity index, and Simpson's diversity index were $0.092,3.733 \pm 0.0071,4.477,0.834,12.667$ and $0.039 \pm 0.0003$ respectively. The highest Importance Value Index (IVI) was found for Acacia auriculiformis (23.23) followed by Tectona grandis (13.05), Gmelina arborea (12.66), Syzygium fruticosum (12.34), Casuarina equisetifolia (10.57), and Dipterocarpus turbinatus (10.55). Height range of $3-<8 \mathrm{~m}$ and dbh class of $5-<15 \mathrm{~cm}$ had the highest percentage of individuals with $59.83 \%$ and $65.97 \%$, respectively. The outcome of present study suggests the protection, sustainable management, and conservation of the tree resources of HNP, Cox's Bazar, Bangladesh.
\end{abstract}

Keywords: Basal area, density, diversity indices, conservation, importance value index

\section{INTRODUCTION}

The vegetation of Bangladesh is a part of the IndoMyanmar region, which is one of the ten global biodiversity hotspots (Mittermeier et al. 1998) and possesses rich biological diversity due to its unique geophysical characteristics (Chowdhury 2001; Hossain 2001; Nishat et al. 2002). In terms of flora, Bangladesh has a rich biological heritage containing about 3,611 flowering plants (Ahmed et al. 2008) of which 2,260 species are reported from Chittagong region alone (Khan et al. 2008).

The diversity of trees is fundamental in representing total biodiversity in tropical forests (Canon et al. 1998) because forest trees provide resources and habitats for almost all other forest organisms (Canon et al. 1998; Huston 1994). Tree species diversity may serve as a preliminary indicator of diversity of plants in a forest type. Moreover, information on diversity, floristic composition and their quantitative structure are vital for understanding the functioning and dynamics of forest ecosystems (Hossain et al. 2015). A higher number of tree species increases the number of associated species such as understory plants and animals. An understanding of phytosociological characteristics of tree species diversity is necessary to facilitate the planning and implementation of more effective conservation measures for sustainable management of tropical forests (Pielou 1995; Feroz et al. 2014; Biswas and Misbahuzzaman 2008).

The extent of biodiversity loss in Bangladesh is not exactly known due to very poor databases and scarce information (Hossain et al. 2004). Numerous plant species in the country are also at risk of being lost in all or part of their distribution ranges because of their population decline caused by overexploitation. The depletion of native species was also accelerating at an alarming rate (Rahman et al. 2000) as the impact of the rapid loss and degradation of forests in Bangladesh. In Bangladesh, it is an urgent need to effectively protect and manage the existing natural forests for sustainable livelihoods (Hossain et al. 2018; Hossain et al. 2019) for the future generation. Quantitative floristic inventories are fundamental to an understanding of the ecology of tropical forests and for developing national forest management strategies.

Himchari National Park (HNP), located in southeastern region of Bangladesh comprising an area of 1729 ha, is very important conservation area due to its proximity to Cox's Bazar tourist city. The forest was rich in floral and faunal diversity (Hossen et al. 2019), unfortunately, it is now heavily pressured by anthropogenic factors like encroachment, illegal felling, and conversion of land to agriculture and betel leaf cultivation (Hossen et al. 2019a). Therefore, the present study was undertaken to determine the structure, composition, and to make an inventory of tree species of HNP. We expected the results of this study can 
serve as baseline information for monitoring the dynamics of tree vegetation in the national park and for developing management and conservation strategies.

\section{MATERIALS AND METHODS}

\section{Study area}

Himchari National Park (HNP) geographically lies at $21^{\circ} 35^{\prime}$ to $21^{\circ} 44^{\prime} \mathrm{N}$ and $91^{\circ} 98^{\circ}$ to $92^{\circ} 05^{\circ} \mathrm{E}$ and is located on the outskirts of Cox's Bazar city extending from Lighthouse para on the north to Rejhukhal on the south (Hossen et al. 2019a, 2019b). It consists of three unions namely South Mithachari, Jhillonja, and Khuniapalong union. The park area is about 1,729 ha. The Protected Forest (PF) is about 10,849 ha of which 1,729 ha core zone, 5,247 ha buffer zone, and 3,873 ha private land (Figure 1). The area lies under the tropical climate zone having monsoon rainfall and climate. Normal rainfall occurs during the month of May to September for five months. The temperature in the area varies between $14.3{ }^{\circ} \mathrm{C}$ and $31.85{ }^{\circ} \mathrm{C}$ (Hossen et al. 2019a). The hills are elevated from the south and west towards the east and the north. The landscape has a broken topography comprising of steep hills and V-shaped valleys. The topography of the park area is almost flat and undulated low rolling hills (Hossen et al. 2019a).

\section{Sampling design}

The study was conducted from January 2017 to May 2018. The composition and diversity of the tree species in Himchari National Park (HNP) were assessed through stratified random sampling methods applied separately for tree species. Considering beat (smallest administrative forest unit) area namely Chainda (62 ha), Jhilongja (450 ha), Kolatoli (872 ha), and Link Road (345 ha), the whole HNP was divided into four broad areas (1,729 ha) (Hossen et al. $2019 b$ ). Fifty-one quadrats in four sampled sites were established. The number of quadrats was fixed considering the sample plot size $(20 \mathrm{~m} \times 20 \mathrm{~m})$ to have a sampling intensity of more than $0.117 \%$ for quantitative measurement of the tree species throughout the park area/sites. All trees in the quadrats with $\mathrm{dbh}$ of $\geq 5 \mathrm{~cm}$ were recorded and identified by expert, counted the number of individuals, and measured. The stem/tree relative density, relative frequency, relative abundance, and Importance Value Index (IVI) were calculated following Shukla and Chandal (2000). Different diversity indices were analyzed following several references (e.g. Pielou 1995; Hossen et al. 2019a, 2019c; Odum 1971) to obtain overview of tree diversity in HNP. Empirical data (height, dbh, etc.) were analyzed using MS Excel.

\section{RESULTS AND DISCUSSION}

\section{Species richness and abundance of trees}

Eighty-eight species ( $\mathrm{dbh} \geq 5 \mathrm{~cm}$ ) belonging to 64 genera and 37 families were recorded. The species richness was highest in the Chainda (59 species) beat and lowest in the Jhilongja beat (Table 1). The most dominant families were the Moraceae with 11 species and 2 genera followed by the Mimosaceae (8 species and 5 genera) (Table 2). Family basal area was highest in Moraceae $\left(4.31 \mathrm{~m}^{2}\right)$ family followed by Mimosaceae (3.38 $\mathrm{m}^{2}$ ) (Table 2).

A total of 961 individual tree stems having $\mathrm{dbh} \geq 5 \mathrm{~cm}$ were counted from the sampled area under the four beats (Table 2). Stem density (562 stems ha ${ }^{-1}$ ) was highest in Kolatoli beat followed by Chainda ( 518 stems ha-1), Link Road (379 stems ha ${ }^{-1}$ ), and Jhilongja (368 stems ha- ${ }^{-1}$ ) (Table 1). Basal area $\left(13.38 \mathrm{~m}^{2} \mathrm{ha}^{-1}\right)$ was highest in the Chainda beat followed by Kolatoli $\left(12.99 \mathrm{~m}^{2} \mathrm{ha}^{-1}\right)$, Link Road $\left(12.29 \mathrm{~m}^{2} \mathrm{ha}^{-1}\right)$, and Jhilongja $\left(5.25 \mathrm{~m}^{2} \mathrm{ha}^{-1}\right)$.
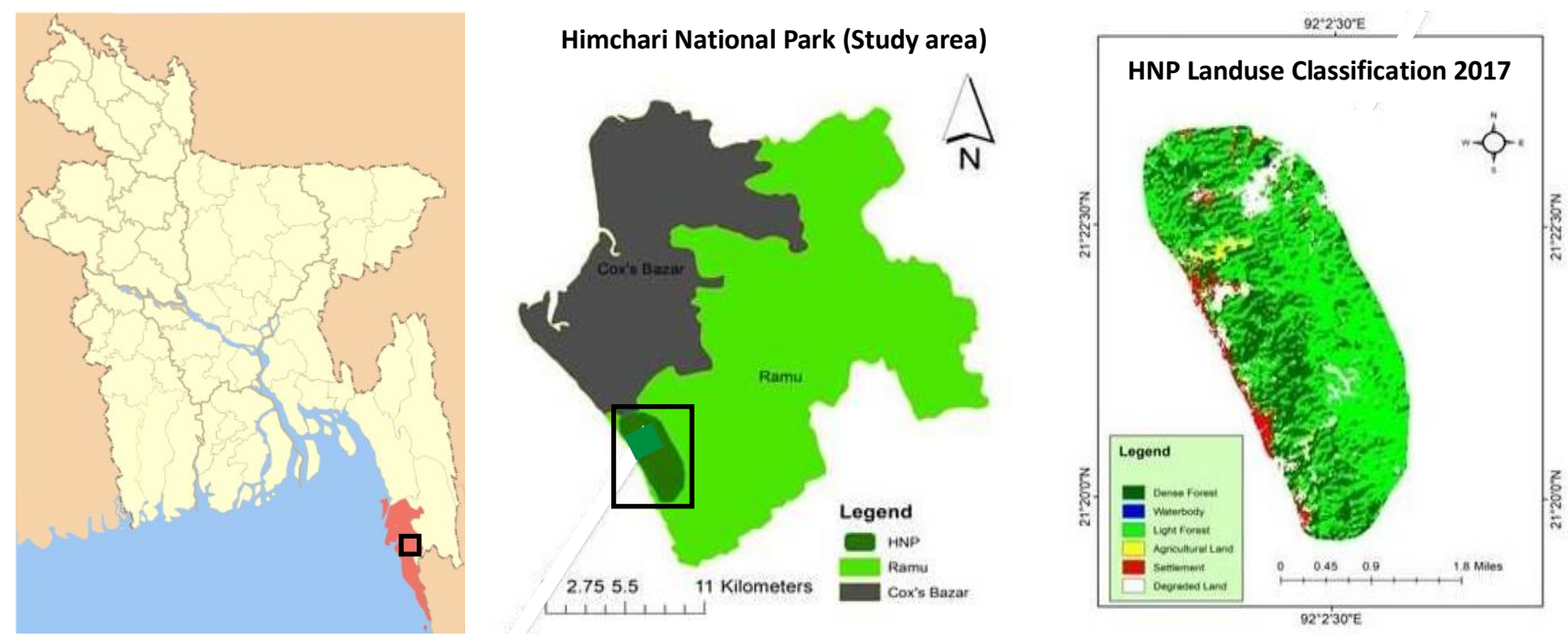

Figure 1. Location of Himchari National Park (HNP) at Cox's Bazar District, Bangladesh 
Table 1. Tree species density and basal area of the trees in the four forest beats

\begin{tabular}{lcccc}
\hline Density and basal area & Kolatoli & Chainda & Jhilongja & Link road \\
\hline No. of representing tree species & 49 & 59 & 37 & 46 \\
Density $\left(\right.$ Stem ha $\left.{ }^{-1}\right)$ & 562 & 518 & 368 & 379 \\
Basal Area $\left(\mathrm{m}^{2} \mathrm{ha}^{-1)}\right.$ & 12.99 & 13.38 & 5.25 & 12.29 \\
\hline
\end{tabular}

Table 2. Family basal area $\left(\mathrm{m}^{2}\right)$, number of genus, species, and number of individual tree stems

\begin{tabular}{|c|c|c|c|c|}
\hline Family & $\begin{array}{c}\text { Basal } \\
\text { area } \\
\left(\mathbf{m}^{2}\right) \\
\end{array}$ & $\begin{array}{l}\text { No. of } \\
\text { genus }\end{array}$ & $\begin{array}{c}\text { No. of } \\
\text { species }\end{array}$ & $\begin{array}{c}\text { No. of } \\
\text { individual } \\
\text { tree stems }\end{array}$ \\
\hline Anacardiaceae & 1.31 & 2 & 2 & 47 \\
\hline Annonaceae & 0.01 & 1 & 1 & 1 \\
\hline Apocynaceae & 0.85 & 1 & 1 & 18 \\
\hline Arecaceae & 0.17 & 1 & 1 & 2 \\
\hline Bignoniaceae & 0.01 & 1 & 2 & 2 \\
\hline Bombacaceae & 0.17 & 1 & 1 & 1 \\
\hline Burseraceae & 0.02 & 2 & 2 & 4 \\
\hline Caesalpiniaceae & 0.72 & 5 & 5 & 28 \\
\hline Casuarinaceae & 1.41 & 1 & 1 & 24 \\
\hline Clusiaceae & 0.08 & 1 & 2 & 4 \\
\hline Combretaceae & 0.52 & 1 & 4 & 42 \\
\hline Dilleniaceae & 0.01 & 1 & 1 & 2 \\
\hline Dipterocarpaceae & 0.64 & 2 & 2 & 72 \\
\hline Ebenaceae & 0.01 & 1 & 1 & 2 \\
\hline Elaeocarpaceae & 0.33 & 1 & 2 & 17 \\
\hline Euphorbiaceae & 0.38 & 2 & 2 & 24 \\
\hline Fabaceae & 0.8 & 2 & 2 & 30 \\
\hline Fagaceae & 0.01 & 2 & 2 & 2 \\
\hline Juglandaceae & 0.04 & 1 & 1 & 3 \\
\hline Lauraceae & 0.02 & 1 & 1 & 6 \\
\hline Lythraceae & 0.26 & 1 & 2 & 16 \\
\hline Magnoliaceae & 0.04 & 1 & 1 & 3 \\
\hline Meliaceae & 1.0 & 5 & 5 & 68 \\
\hline Mimosaceae & 3.38 & 5 & 8 & 168 \\
\hline Moraceae & 4.31 & 2 & 11 & 89 \\
\hline Myrtaceae & 2.55 & 3 & 5 & 97 \\
\hline Myrsinaceae & 0.01 & 1 & 1 & 1 \\
\hline Oxalidaceae & 0.01 & 1 & 1 & 2 \\
\hline Rhamnaceae & 0.29 & 1 & 2 & 17 \\
\hline Rubiaceae & 0.93 & 2 & 2 & 16 \\
\hline Rutaceae & 0.01 & 2 & 2 & 3 \\
\hline Sabiaceae & 0.02 & 1 & 1 & 2 \\
\hline Sapindaceae & 0.01 & 1 & 1 & 1 \\
\hline Sapotaceae & 0.02 & 1 & 1 & 2 \\
\hline Thymeliaceae & 0.01 & 1 & 1 & 2 \\
\hline Tiliaceae & 0.78 & 2 & 4 & 27 \\
\hline Verbenaceae & 2.09 & 4 & 4 & 116 \\
\hline Total & 23.23 & 64 & 88 & 961 \\
\hline
\end{tabular}

\section{Diversity indices}

The stem density was 457.39 stems ha ${ }^{-1}$ and basal area was $10.979 \mathrm{~m}^{2} \mathrm{ha}^{-1}$. The value of species diversity index in the whole survey area was 0.092 . The Shannon-Wiener's diversity index in the area was $3.733 \pm 0.0071$ with Shannon's maximum diversity index of 4.477 . The species evenness index was 0.834 . Margalef's diversity index was 12.667. Simpson's diversity index was $0.039 \pm 0.0003$ (Table 3).

\section{Phytosociological characters of the tree species}

The basal area, stem density, relative density, relative frequency, relative abundance, relative dominance, and Importance Value Index (IVI) of the recorded tree species are shown in Table 4. Fifteen (15) dominant tree species accounted for $59.73 \%$ of the total recorded tree individuals. The highest IVI was found for Acacia auriculiformis (23.23) followed by Tectona grandis (13.05), Gmelina arborea (12.66), Syzygium fruticosum (12.34), Casuarina equisetifolia (10.57), and Dipterocarpus turbinatus (10.55) (Table 4).

\section{Structural composition based on height class distribution}

The distribution height class shows that height range of $3-<8 \mathrm{~m}$ had the highest $(59.83 \%)$ percentage of tree individuals. The lowest percentage $(0.62 \%)$ was represented by the height range of $23-<28 \mathrm{~m}$ (Figure 2). Different height classes were found dominated by different tree species. But, Acacia auriculiformis was found dominating in height classes $3-<8 \mathrm{~m}, 8-<13 \mathrm{~m}$, and 13 $<18 \mathrm{~m}$, respectively. Height range $18-<23 \mathrm{~m}$ was dominated by old-growth Casuarina equisetifolia $(0.42 \%)$ followed by Bombax insigne $(0.21 \%)$ and Eucalyptus camaldulensis $(0.104 \%)$. Height range $23-<28 \mathrm{~m}$ was also dominated by Casuarina equisetifolia $(0.62 \%)$. It was also found that both the number of species and number of individuals decreased regularly with the increase of total tree height. Both the number of tree species and number of individuals (80 species; 575 individuals) were highest in the height range of $3-<8 \mathrm{~m}$ and lowest (1 species and 6 individuals) in height range of $23-<28 \mathrm{~m}$ (Figure 2).

Table 3. Density, basal area, and tree diversity indices of the Himchari National Park (HNP), Cox's Bazar District, Bangladesh

\begin{tabular}{ll}
\hline Diversity indices & Total for HNP \\
\hline & \\
Density $\left(\mathrm{stem} \mathrm{ha}^{-1}\right)$ & 457.39 \\
Basal area $\left(\mathrm{m}^{2} \mathrm{ha}^{-1}\right)$ & 10.979 \\
Species diversity index (SDi) & 0.092 \\
Shannon-Wiener's diversity index (H) & $3.733 \pm 0.0071$ \\
Shannon's maximum diversity index (Hmax) & 4.477 \\
Species evenness index & 0.834 \\
Margalef's diversity index (R) & 12.667 \\
Simpson's diversity index (D) & $0.039 \pm 0.0003$ \\
Dominance of Simpson's index (D') & 0.961 \\
Simpson's reciprocal index (Dr) & 25.641 \\
&
\end{tabular}


Table 4. Phytosociological characters of the tree species in Himchari National Park (HNP), Cox's Bazar District, Bangladesh

\begin{tabular}{|c|c|c|c|c|c|c|}
\hline Botanical name & $\mathbf{B A}\left(\mathbf{m}^{2}\right)$ & Stem no. & RD $(\%)$ & RF (\%) & $\operatorname{Rdo}(\%)$ & IVI \\
\hline Acacia auriculiformis A. Cunn. ex Benth. & 1.199 & 128 & 13.32 & 4.64 & 5.27 & 23.23 \\
\hline Acacia mangium Willd & 0.383 & 14 & 1.46 & 1.03 & 1.68 & 4.17 \\
\hline Acronychia pedunculata (L.) Miq. & 0.003 & 1 & 0.10 & 0.17 & 0.01 & 0.29 \\
\hline Albizia chinensis (Osb.) Merr. & 0.115 & 1 & 0.10 & 0.17 & 0.51 & 0.78 \\
\hline Albizia lebbeck (L.) Benth. \& Hook. & 0.281 & 5 & 0.52 & 0.69 & 1.24 & 2.44 \\
\hline Albizia procera (Roxb.) Benth. & 0.297 & 6 & 0.62 & 1.03 & 1.31 & 2.96 \\
\hline Alstonia scholaris $(\mathrm{L})$. & 0.846 & 18 & 1.87 & 2.58 & 3.72 & 8.17 \\
\hline Aphanamixis polystachya (Wall.) Parker. & 0.005 & 1 & 0.10 & 0.17 & 0.02 & 0.30 \\
\hline Aquilaria agallocha Roxb. & 0.01 & 1 & 0.10 & 0.17 & 0.04 & 0.32 \\
\hline Artocarpus chama Buch.-Ham. & 1.501 & 11 & 1.14 & 1.55 & 6.60 & 9.29 \\
\hline Artocarpus heterophyllus Lamk. & 0.841 & 11 & 1.14 & 2.75 & 3.70 & 7.59 \\
\hline Artocarpus lacucha Buch.-Ham & 0.111 & 3 & 0.31 & 0.52 & 0.49 & 1.32 \\
\hline Averrhoa carambola $\mathrm{L}$. & 0.004 & 1 & 0.10 & 0.17 & 0.02 & 0.29 \\
\hline Azadirachta indica A. Juss & 0.248 & 18 & 1.87 & 2.06 & 1.09 & 5.03 \\
\hline Bombax insigne Wall. & 0.172 & 3 & 0.31 & 0.34 & 0.76 & 1.41 \\
\hline Borassus flabellifer $\mathrm{L}$. & 0.135 & 1 & 0.10 & 0.17 & 0.59 & 0.87 \\
\hline Brownlowia elata Roxb. & 0.016 & 5 & 0.52 & 0.86 & 0.07 & 1.45 \\
\hline Butea monosperma (Lamk.) Taub. & 0.691 & 21 & 2.19 & 2.41 & 3.04 & 7.63 \\
\hline Caesalpinia pulcherrima (L.) & 0.211 & 6 & 0.62 & 0.34 & 0.93 & 1.90 \\
\hline Callicarpa arborea Roxb. & 0.028 & 11 & 1.14 & 1.72 & 0.12 & 2.99 \\
\hline Cassia fistula $\mathrm{L}$. & 0.109 & 9 & 0.94 & 1.03 & 0.48 & 2.45 \\
\hline Casuarina equisetifolia Forst. & 1.407 & 24 & 2.50 & 1.89 & 6.19 & 10.57 \\
\hline Chukrasia tabularis A. Juss. & 0.249 & 19 & 1.98 & 1.72 & 1.09 & 4.79 \\
\hline Citrus maxima (Burm.) Merr. & 0.005 & 2 & 0.21 & 0.17 & 0.02 & 0.40 \\
\hline Delonix regia Rafin. & 0.331 & 8 & 0.83 & 0.86 & 1.46 & 3.15 \\
\hline Dillenia scabrella Roxb. ex Wall & 0.005 & 2 & 0.21 & 0.17 & 0.02 & 0.40 \\
\hline Diospyros montana Roxb. & 0.007 & 2 & 0.21 & 0.17 & 0.03 & 0.41 \\
\hline Dipterocarpus turbinatus Gaertin. & 0.366 & 43 & 4.47 & 4.47 & 1.61 & 10.55 \\
\hline Elaeis guineensis Jacq. & 0.032 & 1 & 0.10 & 0.17 & 0.14 & 0.42 \\
\hline Elaeocarpus floribundus Blume. & 0.003 & 1 & 0.10 & 0.17 & 0.01 & 0.29 \\
\hline Elaeocarpus tectorius (Lour.) Poir & 0.329 & 16 & 1.66 & 2.58 & 1.45 & 5.69 \\
\hline Engelhardtia spicata Leschen ex Blume & 0.037 & 3 & 0.31 & 0.34 & 0.16 & 0.82 \\
\hline Erythrina variegata L. & 0.114 & 10 & 1.04 & 0.86 & 0.50 & 2.40 \\
\hline Eucalyptus camaldulensis Dehnhardt. & 0.672 & 22 & 2.29 & 1.72 & 2.95 & 6.96 \\
\hline Ficus auriculata Lour. & 0.033 & 2 & 0.21 & 0.34 & 0.15 & 0.70 \\
\hline Ficus benghalensis L. & 0.493 & 3 & 0.31 & 0.52 & 2.17 & 2.99 \\
\hline Ficus benjamina $\mathrm{L}$. & 0.046 & 1 & 0.10 & 0.17 & 0.20 & 0.48 \\
\hline Ficus hispida L.f. & 0.436 & 36 & 3.75 & 4.30 & 1.92 & 9.96 \\
\hline Ficus lamponga Miq. & 0.127 & 1 & 0.10 & 0.17 & 0.56 & 0.83 \\
\hline Ficus lanceolata Buch.-Ham. ex Roxb. & 0.007 & 1 & 0.10 & 0.17 & 0.03 & 0.31 \\
\hline Ficus microcarpa L.f. & 0.128 & 2 & 0.21 & 0.34 & 0.56 & 1.11 \\
\hline Ficus racemosa $\mathrm{L}$. & 0.024 & 1 & 0.10 & 0.17 & 0.11 & 0.38 \\
\hline Ficus religiosa $\mathrm{L}$. & 0.559 & 8 & 0.83 & 1.37 & 2.46 & 4.66 \\
\hline Garcinia cowa Roxb. ex DC. & 0.082 & 4 & 0.42 & 0.52 & 0.36 & 1.29 \\
\hline Garuga pinnata Roxb. & 0.013 & 2 & 0.21 & 0.34 & 0.06 & 0.61 \\
\hline Gmelina arborea Roxb. & 0.836 & 55 & 5.72 & 3.26 & 3.68 & 12.66 \\
\hline Grewia nervosa (Lour.) Panigrahi & 0.318 & 22 & 2.29 & 2.92 & 1.40 & 6.61 \\
\hline Hopea odorata Roxb. & 0.014 & 1 & 0.10 & 0.17 & 0.06 & 0.34 \\
\hline Lagerstroemia speciosa (L.) Pers. & 0.264 & 16 & 1.66 & 2.06 & 1.16 & 4.89 \\
\hline Lannea coromandelica (Houtt.) Merr. & 0.078 & 6 & 0.62 & 1.03 & 0.34 & 2.00 \\
\hline Lepisanthes rubiginosa (Roxb.) Leenh & 0.002 & 1 & 0.10 & 0.17 & 0.01 & 0.28 \\
\hline Leucaena leucocephala (Lamk.) de Wit & 0.006 & 1 & 0.10 & 0.17 & 0.03 & 0.30 \\
\hline Lithocarpus elegans (Blume) Hatus.ex Soepad & 0.004 & 1 & 0.10 & 0.17 & 0.02 & 0.29 \\
\hline Lithocarpus polystachya (Wall.ex A.DC.) Rehder & 0.007 & 1 & 0.10 & 0.17 & 0.03 & 0.31 \\
\hline Litsea glutinosa (Lour.) C.B. Robinson & 0.013 & 6 & 0.62 & 0.86 & 0.06 & 1.54 \\
\hline Macaranga denticulata (Bl.)Muell.-Arg. & 0.008 & 3 & 0.31 & 0.34 & 0.04 & 0.69 \\
\hline Macaranga indica Wight & 0.002 & 1 & 0.10 & 0.17 & 0.01 & 0.28 \\
\hline Mangifera indica $\mathrm{L}$. & 0.908 & 29 & 3.02 & 3.26 & 3.99 & 10.27 \\
\hline Mangifera sylvatica Roxb. & 0.321 & 13 & 1.35 & 2.23 & 1.41 & 5.00 \\
\hline Meliosma simplicifolia (Roxb.)Walp. & 0.006 & 2 & 0.21 & 0.17 & 0.03 & 0.41 \\
\hline Michelia champaca $\mathrm{L}$. & 0.035 & 3 & 0.31 & 0.52 & 0.15 & 0.98 \\
\hline Mimusops elengi L. & 0.021 & 2 & 0.21 & 0.17 & 0.09 & 0.47 \\
\hline Mitragyna parvifolia (Roxb.) Korth & 0.024 & 4 & 0.42 & 0.69 & 0.11 & 1.21 \\
\hline
\end{tabular}


Neolamarckia cadamba (Roxb.) Bosser

Phyllanthus emblica $\mathrm{L}$.

Polyalthia longifolia (Sonn.)

Protium serratum (Wall. ex.Colebr.) Engl.

Psidium guajava $\mathrm{L}$.

Samanea saman (Jacq.) Merr.

Senna siamea (Lamk.)

Shorea robusta Roxb. ex Gaertin. f.

Sterculia villosa Roxb. ex Smith

Stereospermum colais (Buch.-Ham. ex Dillw)

Stereospermum suaveolens (Roxb.)

Swietenia mahagoni Jacq.

Syzygium cumini (L.) Skeels

Syzygium firmum Thw.

Syzygium fruticosum DC

Tamarindus indica $\mathrm{L}$.

Tectona grandis L.f.

Terminalia arjuna (Roxb. ex Dc.) Wight \& Am.

Terminalia bellirica (Gaertin.) Roxb.

Terminalia catappa $\mathrm{L}$.

Terminalia chebula Retz.

Toona ciliate Roem.

Vitex peduncularis Wall. ex Schauer in A.DC.

Xylia xylocarpa Roxb. Taub.

Ziziphus mauritiana Lamk.

0.904
0.368
0.011
0.007
0.111
1.055
0.035
0.258
0.004
0.015
0.014
0.486
0.178
0.211
1.377
0.032
1.222
0.277
0.093
0.018
0.147
0.009
0.003
0.048
0.287
22.748

$12 \quad 1.25$

$22 \quad 2.29$

$1 \quad 0.10$

$2 \quad 0.21$

$26 \quad 2.71$

$12 \quad 1.25$

$2 \quad 0.21$

$28 \quad 2.91$

0.10

0.10

0.10

2.91

0.73

1.56

3.02

0.42

5.10

3.43

0.21

0.10

0.62

0.42

0.10

0.10

1.77
1.89

2.92

0.17

0.34

3.61

1.55

0.34

2.23

0.17

0.17

1.89

2.06

0.69

2.41

3.26

0.69

2.58

2.06

0.34

0.17

0.86

0.17

0.17

0.17

2.23

2.23
100
3.97

1.62

0.05

0.03

0.49

4.64

0.15

1.13

0.02

0.07

0.06

2.14

0.78

0.93

6.05

0.14

5.37

1.22

0.41

0.08

0.65

0.04

0.01

0.21

1.26 100
7.11

6.83

0.32

0.58

6.80

7.43

0.71

6.28

0.29

0.34

2.06

7.11

2.20

4.89

12.34

1.24

13.05

6.71

0.96

0.36

2.13

0.63

0.29

0.49

5.26 300

Note: BA: Basal Area, RD: Relative Density, RF: Relative Frequency, RDo: Relative Dominance and IVI : Importance Value Index

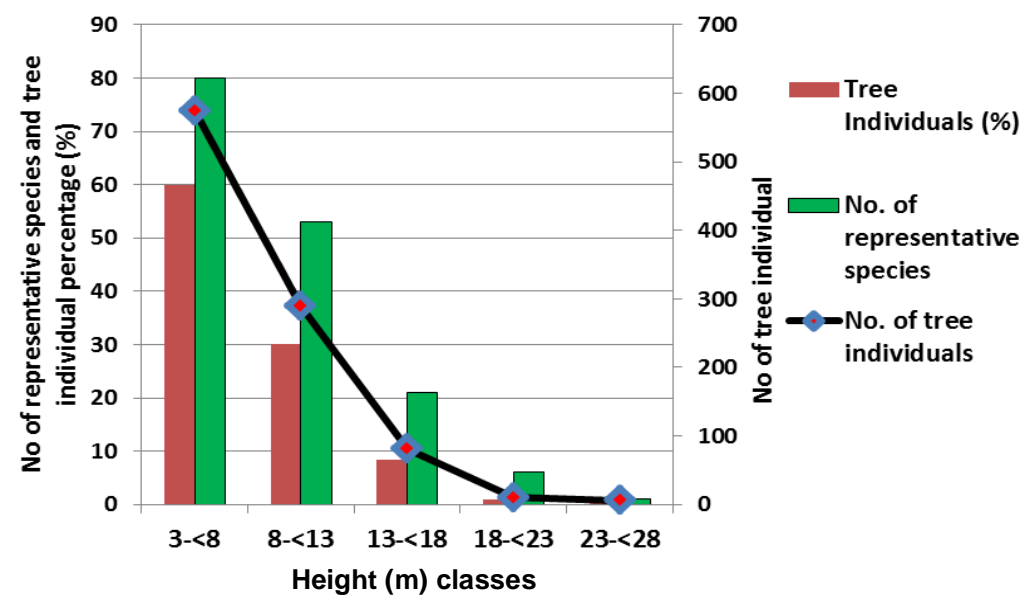

Figure 2. Distribution of tree species and individual number in different height (m) classes of Himchari National Park (HNP), Cox's Bazar District, Bangladesh

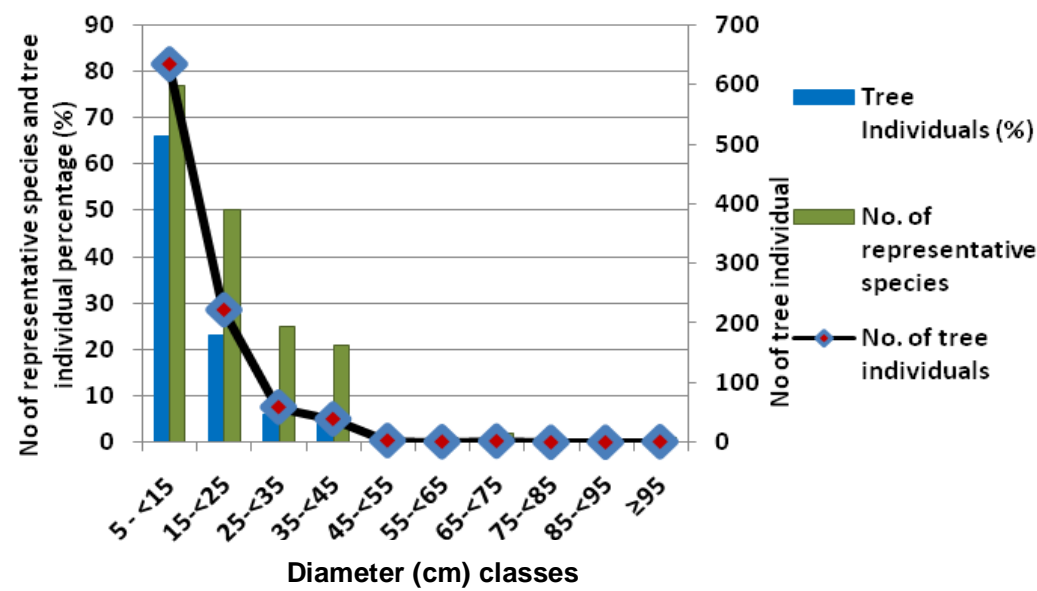

Figure 3. Distribution of tree species and individual number in different dbh (cm) classes of Himchari National Park (HNP), Cox's Bazar District, Bangladesh 


\section{Structural composition based on diameter class distribution}

The distribution of dbh classes shows that most of the trees $(65.97 \%)$ belonged to dbh range $5-<15 \mathrm{~cm}$. Different tree species were found to dominate in different $\mathrm{dbh}$ classes. But, dbh range $5-<15 \mathrm{~cm}$ was dominated by Acacia auriculiformis (11.34\%) followed by Gmelina arborea (4.99\%). The number of species and tree individuals was found to decrease with increasing diameter with very little exception. Both the tree species and individuals were the highest $(77$ species and 634 individuals) in $5-<15 \mathrm{~cm}$ dbh range (Figure 3). As the dbh increased, both the number of species and number of tree individuals decreased.

\section{Discussion}

\section{Tree species abundance}

The tree species composition of HNP found in 51 quadrats (88 tree species, 64 genera, 37 families) was higher than many tropical forests, i.e. 38 tree species in Ukhia Range of Cox's Bazar (Ahmed and Haque 1993), 50 tree species belonging to 28 families in Rampahar Natural Forest (Malaker et al. 2010), 78 tree species in Lawachara forest (Malaker et al. 2010), 85 tree species in Sitapahar Reserve forest of Chittagong Hill Tracts (South) Forest Division (Nath et al. 1998), 85 tree species in Bamu reserve forest of Cox's Bazar (Hossain et al. 1997), and 62 tree species in Tankawati natural forest (Motaleb and Hossain 2011). However, the tree species diversity was comparatively lower than 150 tree species in Teknaf Wildlife Sanctuary (Uddin et al. 2013), 151 tree species in Inani Protected Forest (Nath et al. 2000), 143 tree species in Teknaf Wildlife Sanctuary (Feeroz 2013), 92 tree species in Chunati Wildlife Sanctuary (Rahman and Hossain 2003) and 400 tree species in the forests of Sylhet (Alam 2008) in Bangladesh. However, considering the results of these similar studies, it can be inferred that the HNP possesses comparatively well-diversified natural forests with higher number of tree species.

The stem density (457.39 stems ha $^{-1}$ ) ranks highest in comparison to $381 \mathrm{stems} \mathrm{ha}^{-1}$ (but it was $>10 \mathrm{~cm}$ diameter) in Sitapahar reserve forest of Chittagong Hill Tracts (South) Forest Division (Nath et al. 1998), 257 stems ha $^{-1}$ in Ukhia Natural Forests of Cox's Bazar (Ahmed and

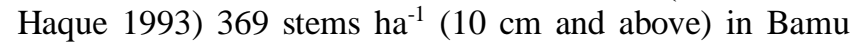
reserve forests of Cox's Bazar (Hossain et al. 1997), but lower than 709 stems $^{-1}$ in Tropical Forest of Eastern Ghats, India (Reddy et al. 2011).

\section{Basal area and diversity indices}

From the value of basal area, it seems that the trees in the HNP were large in diameter. The basal area $\left(10.979 \mathrm{~m}^{2}\right.$ $\left.\mathrm{ha}^{-1}\right)$ of HNP was much lower than that of $53.5 \mathrm{~m}^{2} \mathrm{ha}^{-1}$ in Sitapahar reserve forests of Chittagong Hill Tracts (South) Forest Division (Nath et al. 1998) or $47.02-62.16 \mathrm{~m}^{2} \mathrm{ha}^{-1}$ in Tankawati natural forest of Chittagong South Forest Division (Motaleb and Hossain 2011). The lower basal area indicates that the forest area was suffering from illegal felling of mature trees. The lower species diversity index (0.092) indicates the lower number of species with respect to the total number of individuals of all species. The Shannon-Wiener's diversity index $(3.733 \pm 0.0071)$ and Shannon's maximum diversity index (4.477) indicate that even though the HNP was under serious threats, the forests still had a reasonable floristic diversity which needs effective conservation measures for sustainable management. The value of Margalef's diversity index (12.667) indicates proficient presence of tree species in the area. Lower value of Simpson's index $(0.039 \pm 0.0003)$ also indicates the diverse tree species.

\section{Phytosociological characters of the tree species}

The IVI value indicates a complete picture of phytosociological character of a species in the community (Hossain et al. 2004). Acacia auriculiformis possessed the highest IVI values (23.23) followed by Tectona grandis (13.05), Gmelina arborea (12.66), Syzygium fruticosum (12.34), Casuarina equisetifolia (10.57), Dipterocarpus turbinatus (10.55). Acacia auriculiformis had the highest IVI value among planted tree species as well as considering all species indicating that the number of tree species was declining.

The Shannon-Wiener diversity index (3.733) was higher than that of 2.98 in Sithapahar reserve forest (Nath et al. 2000) or 3.25 in Tankawati natural forest of Chittagong (South) Forest Division, but lower than that of 4.27 of Garo Hills of India (Ahmed and Haque 1993). The value of Shannon-Wiener index (3.733), Margalef's index (12.667), and lower value of Simpson's index (0.039) represent the higher diversity in HNP. These values indicate that the restoration and recolonization program of native tree species is essential as to recover the native tree species.

\section{Structural composition based on height class distribution}

Patterns of height $(\mathrm{m})$ class distribution designate general trends of population dynamics and recruitment process to the maximum species in HNP. Considering the other previous studies, distribution of individuals among different height classes showed a reverse J-shaped curve that indicates presence of more or less stable population structure or good regeneration status. That means, as the height class increases, the number of individuals and species are decreasing and indicates that old, mature trees are very scarce in the study area.

\section{Structural composition based on diameter class distribution}

Distribution of individuals among different $\mathrm{dbh}(\mathrm{cm})$ classes showed a reverse J-shaped curve that indicates progressive decrease of tree individuals in larger tree size classes. The number of species and percentage of tree individuals was maximum in the lower $\mathrm{dbh}(\mathrm{cm})$ ranges and the number of tree individuals was progressively decreasing with the increase of dbh $(\mathrm{cm})$. As the dbh increased, both the number of species and number of tree individuals decreased showing successful recruitment of some native species. It also indicates incidence of illegal felling of more or less mature trees, and economically important trees and land-use changes in the National Park. The higher number of trees in lower size classes also 
indicates recent initiatives for conservation, protection, and improvement of the national park.

In conclusion, this study concluded that although the forest in Himchari National Park had been degraded severely, but it harbors a rich diversity of plant species, and the advancement of gradual restoration process initiated after massive anthropogenic disturbances through both artificial and natural means are essential to bringing back the native tree species in HNP. A proper strategy for conservation and management in the study area is required for the best utilization of HNP tree species by the local villagers.

\section{ACKNOWLEDGEMENTS}

The authors are thankful to the taxonomists of Bangladesh Forest Research Institute (BFRI), Divisional Forest Officer and field staff of Cox's Bazar South Forest Division and the local people of HNP for their cordial collaboration and cooperation during the field study.

\section{REFERENCES}

Ahmed GU, Haque SMS. 1993. Percentage distribution of species and diameter class in a natural forest of Bangladesh. Chittagong University Studies Part II: Science (Bangladesh) 17 (1): 109-113

Ahmed ZU, Begum ZNT, Hassan MA, Khondoker M, Kabir SMH, Ahmed M, Ahmed ATA, Rahman AKA, Haque EU. 2008 Encyclopedia of Flora and Fauna of Bangladesh 6. Asiatic Soc Bangladesh, Dhaka.

Alam MK. 2008. Forests and Forestry in Bangladesh. In: Ahmed ZU, Begum ZNT, Hassan MA, Khondker M, Kabir SMH, Ahmed M, Ahmed ATA, Rahman AKA, Haque EU (eds). Encyclopedia of Flora and Fauna of Bangladesh. Vol. 1. Bangladesh Profile. Asiatic Soc Bangladesh, Dhaka.

Biswas SR, Misbahuzzaman K. 2008. Tree species diversity and regeneration traits of the dominant species in a dipterocarp forest in Bangladesh: Implications for conservation. Intl J Biol Sci Manag 4 (2): 81-91. DOI: 10.3843/Biodiv.4.2:2

Canon CH, Peart DR, Leighton M. 1998. Tree species diversity in commercially logged Bornean rain forest. Science 28: 1366-1368.

Chowdhury QI. 2001. Bangladesh: State of Bio-diversity Forum of Environmental Journalists of Bangladesh (FEJB). Shegun Bagicha, Dhaka, Bangladesh.

Feeroz MM. 2013. Biodiversity of Protected Areas of Bangladesh, Vol III: Teknaf Wildlife Sanctuary. BioTrack. Arannayk Foundation. Dhaka, Bangladesh.

Feroz SM, Alam MR, Das P, Mamun AA. 2014. Community ecology and spatial distribution of trees in a tropical wet evergreen forest in Kaptai national park in Chittagong Hill Tracts, Bangladesh. J For Res 25 (2) 311-318. DOI: 10.1007/s11676-013-0423-0

Hossain MA, Hossain MK, Alam MS, Uddin MM. 2015. Composition and Diversity of Tree Species in Kamalachari Natural Forest of Chittagong South Forest Division, Bangladesh. J For Environ Sci 31 (3): 192-201. DOI: 10.7747/JFES.2015.31.3.192

Hossain MA, Hossen S, Akhter J. 2018. Quantifying diversity and composition of tree species in Satchari National Park, Bangladesh. Intl J Usuf Mngt 19: 15-23.

Hossain MK, Hossain M, Alam MK. 1997. Diversity and structural composition of trees in Bamu reserved forest of Cox's Bazar Forest Division, Bangladesh. Bangladesh J For Sci 26 (1): 31-35.

Hossain MK. 2001. Overview of the forest biodiversity in Bangladesh. Assessment, conservation, and sustainable use of forest biodiversity (CBD Technical Series no. 3). Montreal, SCBD, Secretariat of the Convention on Biological Diversity, Canada.
Hossain MK, Rahman ML, Hoque ATMR, Alam MK. 2004. Comparative regeneration status in a natural forest and enrichment plantations of Chittagong (South) Forest Division, Bangladesh. J For Res 15 (4): 255-260. DOI: 10.1007/BF02844948

Hossain MK, Alim A, Hossen S, Hossain MA, Rahman A. 2019. Diversity and conservation status of tree species in Hazarikhil Wildlife Sanctuary (HWS) of Chittagong, Bangladesh. Geol Ecol Landscapes 1-8. DOI: 10.1080/24749508.2019.1694131

Hossen S, Hossain MK. 2018. Conservation status of tree species in Himchari National Park of Cox's Bazar, Bangladesh. J Biodivers Conserv Bioresour Manag 4 (2): 1-10. DOI: 10.3329/jbcbm.v4i2.39842

Hossen S, Hossain MK, Uddin MF. 2019a. Restoration and rehabilitation potential of the remnant natural forests of Himchari National Park (HNP) in Cox's Bazar, Bangladesh. Asian J For 3 (1): 25-30. DOI: 10.13057/asianjfor/r030104

Hossen S, Hossain MK, Uddin MF. 2019b. Land cover and land-use change detection by using remote sensing and GIS in Himchari National Park (HNP), Cox's Bazar, Bangladesh. J Sci Technol Environ Inform 7 (2): 544-554. DOI: 10.18801/jstei.070219.56

Hossen S, Hossain MK, Uddin MF. 2019c. Regeneration potentials of native tree species diversity in Himchari National Park (HNP), Cox's Bazar, Bangladesh. India For 145 (6): 528-534.

Huston MA. 1994. Biological Diversity. The Co-Existence of Species on Changing Landscape. Cambridge University Press, Cambridge.

Khan SMMH, Nishat A, Haque R. 2008. Biodiversity conservation in Bangladesh. In: Ahmed ZU, Begum ZNT, Hassan MA, Khondker M, Kabir SMH, Ahmed M, Ahmed ATA, Rahman AKA, Haque EU (eds) Encyclopedia of Flora and Fauna of Bangladesh. Vol. 1. Bangladesh Profile. Asiatic Soc Bangladesh, Dhaka.

Malaker JC, Rahman MM, Azad-ud-doula Prodhan AKM, Malaker SK, Khan MAH. 2010. Floristic composition of Lawachara forest in Bangladesh. Intl J Expt Agric 1 (2): 1-9.

Mittermeier RA, Myers N, Thomsen JB, Defonseca GA, Olivieri S. 1998. Biodiversity hotspots and major tropical wilderness areas: Approaches to setting conservation priorities. Conserv Biol 12: 516520. DOI: 10.1046/j.1523-1739.1998.012003516.x

Motaleb MA, Hossain MK. 2011. Assessment of tree species diversity of Tankawati natural forests, Chittagong (South) Forest Division, Bangladesh. Eco-Friendly Agric J 4 (2): 542-545.

Nath TK, Hossain MK, Alam MK. 1998. Assessment of tree species diversity of Sitapahar forest reserve, Chittagong Hill Tracts (South) Forest Division, Bangladesh. Ann For 6 (1): 1-9.

Nath TK, Hossain MK, Alam MK 2000. Assessment of tree species diversity of Sitapahar forest reserve, Chittagong Hill Tracts (South) Forest Division, Bangladesh. India For 126: 16-21.

Nishat A, Huq SMI, Barua SP, Reza AHMA, Khan ASM. 2002. Bioecological Zones of Bangladesh. The World Conservation Union (IUCN) Country Office, Dhaka, Bangladesh.

Odum EP. 1971. Fundamentals of Ecology. W.B. Saunders Co, Philadelphia, USA.

Pielou EC. 1995. Biodiversity versus old-style diversity measuring for conservation. In: Boyle TJB, Boontawee B (eds) Measuring and monitoring biodiversity in tropical and temperate forests. Proceedings of an IUFRO Symposium held at Chiang Mai, Thailand in 1994. CIFOR, Indonesia.

Rahman MA, Rashid MH, Wilcock CC. 2000. Diversity, Ecology, Distribution and Ethnobotany of the Apocynaceae of Bangladesh. Bangladesh J Plant Taxon 7 (2): 57-76.

Rahman ML, Hossain MK. 2003. Status of fodder and non-fodder tree species in Chunati Wildlife Sanctuary of Chittagong forest division, Bangladesh. Intl J For Usuf Mngt 4 (2): 9-14.

Reddy CS, Babar S, Amarnath G, Pattanaik C. 2011. Structure and floristic composition of tree stand in tropical forest in the Eastern Ghats of Northern Andhra Pradesh. India J For Res 22 (4): 491-500. DOI: $10.1007 / \mathrm{s} 11676-011-0193-5$

Shukla RS, Chandal PS. 2000. Plant Ecology and Soil Science. Ramnagar: S. Chand and Company Limited, New Delhi, India.

Uddin MZ, Alam MK, Rhaman MA, Hassan MA. 2013. Diversity in angiosperm flora of Teknaf Wildlife Sanctuary, Bangladesh. Bangladesh J Plant Taxon 20 (2): 145-162. DOI: 10.3329/bjpt.v20i2.17389 